\title{
King of the stem cells
}

On 14 September, the California Institute for Regenerative Medicine (CIRM) appointed Australian biologist Alan Trounson as its new president. The CIRM has lacked a permanent director since neuroscientist Zach Hall departed in April, amidst rumours of tension between himself and Robert Klein, chair of the \$3-billion agency's board.

\section{Why were you picked?}

I think the CIRM board was interested in my perspective of wanting to push very hard at the pipeline between discovery and clinical application. I am more interested in getting discoveries through to the clinic than simply commercial operations or research for the sake of research.

\section{What's exciting you in the field?}

There are a lot of options that are brimming with potential. Mesenchymal [multipotent] stem cells are already in clinical trials. Embryonic stem cells (ESCs) are coming of age and I'm interested in the clinical trials proposed by Geron, based in Menlo Park, California, and the University of California, Irvine.

Does the CIRM need to recalibrate its vision because companies don't see ESC therapies as viable? Companies have been a bit too optimistic by looking for cures in very short timeframes. I'd rather the commercialization be a natural spin-off of the pipeline and that's what I think will happen in California.

\section{Given the international expectations and local politics, what is possible at the CIRM?} I've got to live with the current [CIRM] vision and maximize the efficiency of delivery of this medical opportunity to patients. I've got to link in with researchers in other US states, but we should treat this as a global exercise. California will lead it, because they've got such a lot of money and researchers. But if we incorporate our efforts, and minimize duplication and maximize output, this medical revolution will happen more quickly than we expected.

What did you learn from your involvement in politics in Australia?

Be very, very careful what you say. And utilize the politically astute people around you to get the message delivered, rather than trying to take the whole system head on. I would not be inclined to [get involved in politics] again. It was hard going and stressful and clearly I didn't get it right every time, and I apologized for that.

\section{Do you think the CIRM's dual leadership} structure could be awkward?

I've always worked in partnership with people. I worked with Carl Wood to deliver in vitro fertilization. I worked with David de Kretser to set up the Institute of Reproduction and Development at Monash University. All my life I've had partnerships with people who bring a different set of skills from my own. Bob Klein is incredibly good at what he does. He's persuasive, he has a tremendous memory and he's got political connections. I don't have any of that, so creating a partnership with Bob is exactly what should be done.

\section{Is giving up the lab} difficult?

That's hard, but it's time. I could get another paper in Nature or somewhere else, and that's a thrill. But I've made my contribution in the lab. To have a chance to contribute at this level is very exciting.

\section{Why do you call this the best job in stem cells in the world?}

You're working with the best researchers, you've got an enormous amount of money and you've got political will and the people of California behind you. It's a huge challenge, but I think the resources are there to accommodate it.

When will be the first stem-cell therapy? I see it as a continuum. Adult stem cells are happening. Embryonic stem cells will come into use, and they won't be immediate cures for everything. You need drugs and protocols as well as the cells, and you've got to work with the immune system.

Interview by Erika Check Hayden. 